\title{
Gambaran histologik hati tikus Wistar yang diberi jus tomat setelah diinduksi monosodium gluatamat
}

\author{
${ }^{1}$ Christantio Legoh \\ ${ }^{2}$ Martha M. Kaseke \\ ${ }^{2}$ Taufiq F. Pasiak
}

\author{
${ }^{1}$ Kandidat Skripsi Fakultas Kedokteran Universitas Sam Ratulangi Manado \\ ${ }^{2}$ Bagian Ilmu Anatomi Histologi Fakultas Kedokteran Universitas Sam Ratulangi Manado \\ Email: legohjunior@gmail.com
}

\begin{abstract}
Monosodium glutamate (MSG) is one of the ingredients used as flavour additive. However, excessive consumption of MSG could damage the liver. This study was aimed to obtain the impact of MSG exposure on histopathological findings of the liver of Wistar rats administered with tomato juice. This was an experimental study with the post-test only control group design. Subjects were Wistar rats divided into three groups, as follows: the negative control group, treatment group I, and treatment group II. The negative control group was given $\mathrm{AD} 2$ pellets; the treatment group I was given $\mathrm{AD} 2$ pellets and MSG, while the treated group II was given MSG and tomato juice. This study was conducted for 14 days. The histopathological examination of the treatment group I showed fatty degeneration of hepatocytes and infiltration of inflammatory cells meanwhile of the treatment group II, there was less fatty degeneration of hepatocytes compared to the treatment group I and no inflammatory cells. Moreover, there was no fatty degeneration and inflammatory cells in the negative control group. Conclusion: Wistar rats treated with MSG showed fatty degeneration of hepatocytes and infiltration of inflammatory cells which could be reduced by administration of tomato juice along with MSG.
\end{abstract}

Keywords: tomato juice, MSG

\begin{abstract}
Abstrak: Monosodium glutamat (MSG) merupakan salah satu bahan makanan yang sering digunakan sebagai penyedap rasa namun konsumsi MSG berlebihan dapat merusak hati. Penelitian ini bertujuan untuk mengetahui pengaruh pajanan MSG terhadap gambaran histologik hati tikus Wistar dengan dan tanpa disertai pemberian jus tomat. Jenis penelitian ialah eksperimental dengan post-test only control group design. Tikus dibagi menjadi 3 kelompok, yaitu kelompok kontrol negatif, kelompok perlakuan I, dan kelompok perlakuan II. Kelompok kontrol negatif hanya diberikan pelet AD2; kelompok perlakuan 1 diberikan pelet AD2 dan MSG; kelompok perlakuan 2 diberikan MSG dan jus tomat. Penelitian ini dilakukan selama 14 hari. Hasil pengamatan gambaran histologik hati tikus Wistar pada kelompok perlakuan I mendapatkan adanya degenerasi lemak pada hepatosit dan sel-sel radang PMN. Pada kelompok perlakuan 2 masih ditemukan adanya degenerasi lemak pad hepatosit tetapi dengan jumlah yang lebih kurang daripada kelompok perlakuan I, serta tidak ditemukan selsel radang PMN. Pada kelompok kontrol negatif tidak ditemukan adanya degenerasi lemak pada hepatosit dan sel radang. Simpulan: Pada tikus wistar dengan pemberian MSG terdapat degenerasi lemak pada hepatosit dan adanya sel-sel radang. Pemberian jus tomat bersamaan dengan pemberian MSG berefek menurunkan terjadinya degenerasi lemak pada hepatosit dan tidak disertai sel-sel radang.
\end{abstract}

Kata kunci: jus tomat, MSG 
Monosodium Glutamate (MSG) ialah garam sodium dari asam glutamat yang termasuk asam amino non-esensial yang biasa digunakan sebagai penyedap rasa dalam kehidupan sehari-hari. ${ }^{1}$ Garam sodium dapat meningkatkan cita rasa dari suatu makanan sehingga dapat meningkatkan selera. $^{2}$ Konsumsi MSG di Indonesia meningkat dari 100.568 ton pada 1998 menjadi 122.966 ton pada 2004 atau diperkirakan terjadi peningkatan konsumsi sebesar 1,53 g/orang/hari. Negara yang paling sedikit mengonsumsi MSG yaitu Amerika Serikat, dan yang paling banyak yakni Cina, sedangkan di Indonesia, sekitar $77,8 \%$ populasi mengonsumsi $\mathrm{MSG}^{3}$

MSG bersifat sangat larut dalam air dan akan berdisosiasi menjadi kation garam sodium dan anion asam glutamat. ${ }^{4}$ Glutamat di dalam MSG tidak terikat pada molekul protein melainkan dalam bentuk bebas yang dapat membentuk radikal bebas. Konsumsi MSG berlebihan dapat menyebabkan terbentuknya radikal bebas di dalam tubuh. ${ }^{5}$ Stres oksidatif ditandai dengan terbentuknya radikal bebas. Efek radikal bebas dalam tubuh akan dinetralisir oleh antioksidan. Antioksidan dapat dibentuk oleh tubuh sendiri dan suplemen dari luar melalui makanan, minuman, dan obat-obatan, seperti vitamin C, vitamin E, dan lain-lain. ${ }^{6}$

Jus tomat mengandung antioksidan (likopen, vitamin A, dan vitamin C) yang dapat berikatan dengan radikal bebas sehingga mencegah radikal bebas berikatan dengan sel lain didalam tubuh. ${ }^{7}$

Tujuan penelitian ini ialah untuk mengetahui gambaran histopatologik hati tikus Wistar yang diberikan jus tomat setelah diinduksi dengan MSG.

\section{METODE PENELITIAN}

Jenis penelitian ini ialah eksperimental dengan post test only control group design. Subyek penelitian ialah 15 ekor tikus Wistar yang dibagi menjadi 3 kelompok: kelompok I tanpa perlakuan; kelompok II diberikan MSG dengan dosis 4 gr selama 14 hari; dan kelompok III diberikan jus tomat dengan dosis $3 \mathrm{ml}$ dan MSG dengan dosis $4 \mathrm{gr}$ selama 14 hari. Terminasi dilakukan pada hari ke-15. Setelah diterminasi, hati tikus difiksasi dan kemudian dibuat preparat histologik. Preparat diamati dengan menggunakan mikroskop cahaya pembesaran 40x, 100x dan 400x..

\section{HASIL PENELITIAN}

Gambaran histologik dari kelompok tanpa perlakuan yang hanya diberikan air minum dan pellet biasa menunjukkan gambaran hati yang normal (Gambar 1).

Kelompok perlakuan I dengan pemberian MSG menunjukkan gambaran degenerasi lemak pada hepatosit (Gambar 2) disertai infiltrasi sel radang polimorfonuklear (PMN) (Gambar 3).

Kelompok perlakuan II dengan pemberian MSG dan jus tomat memperlihatkan gambaran yang hampir sama. Degenerasi lemak pada hepatosit lebih sedikit dan tidak ditemukan infiltrasi sel radang PMN (Gambar 4).

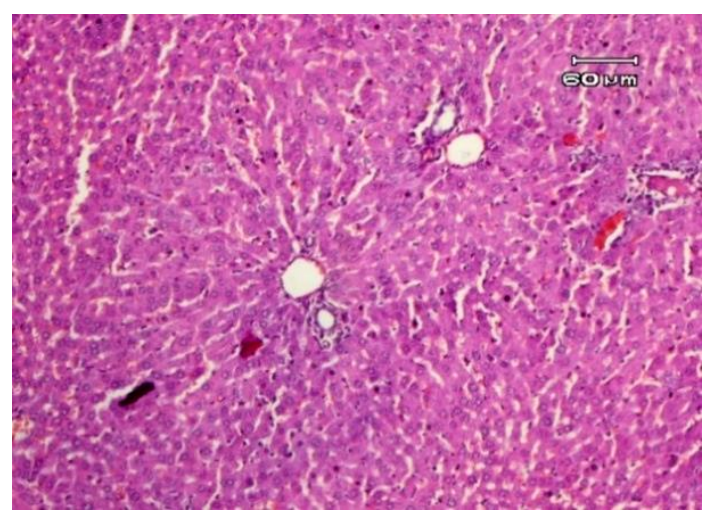

Gambar 1. Gambaran histologik hati tikus tanpa perlakuan. 100x

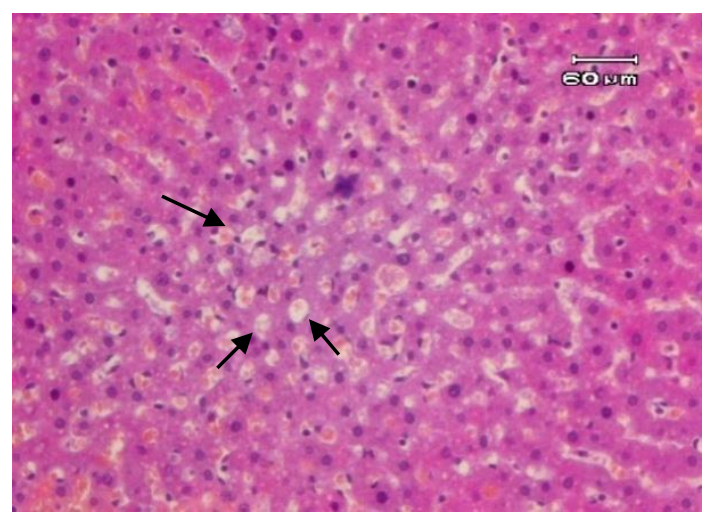

Gambar 2. Gambaran histologik hati tikus dengan pemberian MSG. 100x. 


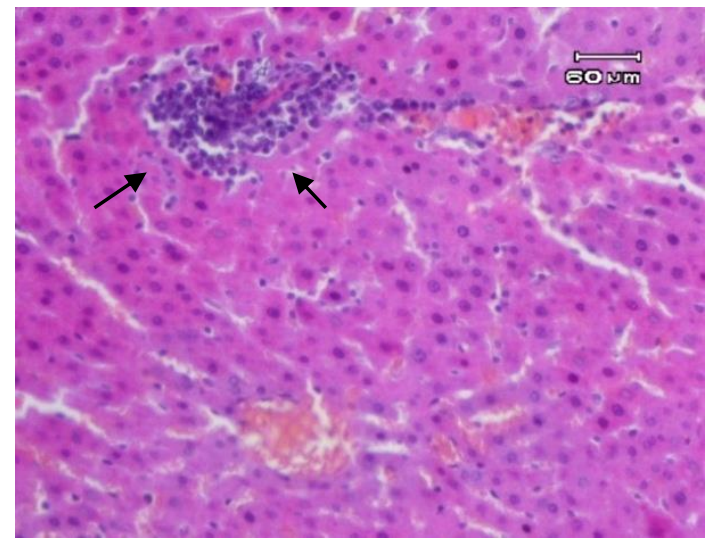

Gambar 3. Gambaran histologik hati tikus dengan pemberian MSG. 100x.

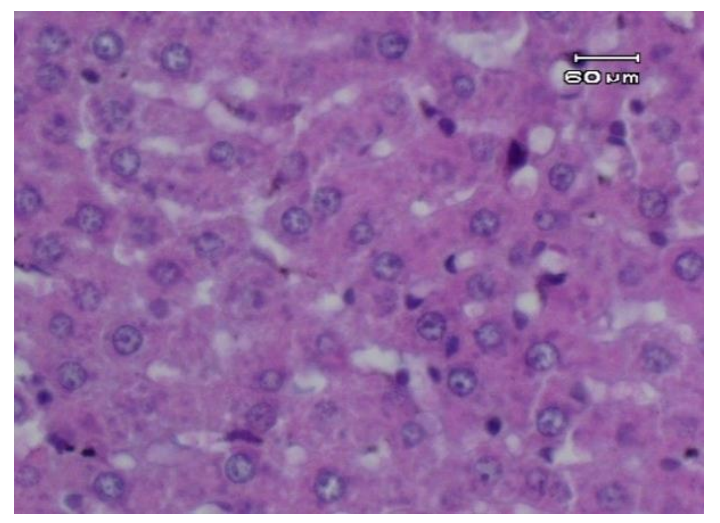

Gambar 4. Gambaran histologik hati tikus dengan pemberian MSG dan jus tomat. 400x.

\section{BAHASAN}

Dari hasil pembacaan, kelompok perlakuan I memiliki gambaran yang hampir sama dengan kelompok perlakuan II namun kelompok perlakuan I dan kelompok perlakuan II memiliki gambaran yang berbeda dengan kelompok tanpa perlakuan. Gambaran mikroskopis yang didapatkan pada kelompok tanpa perlakuan ialah gambaran hati normal, hepatosit tersusun secara radier, vena sentralisnya jelas, inti normokromatis, dan lempeng-lempeng hepatosit beranastomosis secara bebas, yang membatasi celah yang ditempati sinusoid.

Gambaran mikroskopik kelompok perlakuan I dan kelompok perlakuan II memperlihatkan sedikit perbedaan yaitu adanya degenerasi lemak dari hepatosit dan adanya sel-sel radang PMN. Pemberian MSG akan merangsang efek parasimpatik dan menghasilkan asetilkolin dalam darah sehingga kolinesterase meningkat dalam plasma dan merusak jaringan hati. ${ }^{8}$ Penggunaan MSG berlebihan akan menyebabkan terjadinya akumulasi MSG dalam hati yang berfungsi detoksifikasi zatzat toksik yang masuk ke dalam tubuh Akibat akumulasi ini dapat terjadi kerusakan hepatosit oleh kerja radikal bebas yang ditimbulkan oleh penggunaan MSG tersebut. ${ }^{8}$ Hasil penelitian ini juga sejalan dengan penelitian-penelitian sebelumnya mengenai pengaruh pemberian MSG terhadap gambaran histologik hati tikus yang melaporkan terjadinya kelainan berupa perlemakan dan infiltrasi sel-sel radang PMN. ${ }^{8-10}$

Pada kelompok perlakuan II masih dapat ditemukan perlemakan dengan jumlah yang lebih kurang dibandingkan dengan kelompok perlakuan I tanpa adanya sel-sel radang. Hal ini dapat terjadi karena kandungan antioksidan dalam tomat berfungsi untuk menetralkan radikal bebas yang masuk melalui paparan MSG. Sesuai dengan penelitian sebelumnya oleh Tappi et al. ${ }^{11}$ yang mendapatkan pemberian jus tomat dalam dosis $3 \mathrm{ml}$ terbukti dapat memperbaiki hepatosit hati yang sebelumnya diinduksi dengan karbon tetraklorida $\left(\mathrm{CCl}_{4}\right)$. Karbon tetraklorida yang dimetabolisme di hati akan menghasilkan radikal bebas yang dapat merusak hati. ${ }^{11}$ Radikal bebas dapat menyebabkan stres oksidatif yang meningkatkan kerusakan seluler yang disebabkan oleh reactive oxygen species (ROS). Proses ini merupakan ketidakseimbangan antara produksi dan eliminasi dari ROS yaitu terjadi peningkatan dan pembentukan ROS tanpa diimbangi oleh antioksidan di dalam tubuh. Berdasarkan pengamatan gambaran histologik hati tikus Wistar pada kelompok perlakuan 2 yang diberikan MSG dengan dosis 4 gr (dosis toksik) dan juga diberikan jus tomat dengan dosis $3 \mathrm{ml}$, masih dapat ditemukan degenerasi lemak pada hepatosit tetapi tanpa adanya sel-sel radang. Pemberian jus tomat dapat memperbaiki kerusakan hepatosit yang terjadi akibat stres oksidatif karena jus tomat mengandung antioksidan yang dapat mengikat radikal bebas, tetapi karena tikus Wistar 
mengonsumsi MSG yang diberikan setiap hari dalam dosis berlebihan dan pemberian jus tomat dengan dosis yang kurang maksimal maka antioksidan dalam jus tomat tidak dapat memberikan efek yang optimal sehingga masih dapat ditemukan perlemakan.

\section{SIMPULAN}

Berdasarkan hasil penelitian dapat disimpulkan bahwa pada tikus Wistar yang diberi monosodium glutamat (MSG) per oral selama 14 hari didapatkan gambaran histologik hati berupa degenerasi lemak pada hepatosit dan adanya sel-sel radang PMN.

Pada tikus Wistar yang diberikan MSG dan jus tomat didapatkan gambaran degenerasi lemak pada hepatosit yang lebih kurang dibandingkan dengan yang hanya diberikan MSG, dan tanpa adanya sel-sel radang.

\section{SARAN}

1. Sebaiknya masyarakat membatasi penggunaan MSG mengingat efek yang dapat ditimbulkannya.

2. Sebaiknya masyarakat dapat meningkatkan konsumsi tomat dan antioksidan lainnya untuk menangkal radikal bebas yang masuk ke dalam tubuh.

\section{DAFTAR PUSTAKA}

1. The International Glutamate Information Service (IGIS), 2000. Safety of Monosodium Glutamate. [Online] [cited 2016 Sept 18]. Available from: http://www.glutamate.org

2. Food and Drug Administration. FDA and monosodium glutamate (MSG). 1995. [Online]. [cited 2016 Sept 18]. Available from: http://vm.cfsan.fda.gov/lrd/msg.html

3. Riset Kesehatan Dasar. 2007. [Online] [cited 2016 Sept 18]. Available from: http://labmandat.litbang.depkes.go.id

/images/download/laporan/RKD/20

7/lap_rkd07.pdf.

4. Eweka AO, Om'Iniabohs FAE. Histological studies of the effects of monosodium glutamate on the small intestine of adult Wistar rats. Electron J Biomed. 2007;2:14-8.

5. Savira M. Gangguan perkembangan testis dan penurunan kadar testosteron pada hewan coba akibat paparan monosodium glutamate (MSG) yang berlebihan [Tesis]. Medan: Fakultas Kedokteran Universitas Sumatera Utara; 2008.

6. Yusuf AM, Widodo JP, Doddy M, Soebadi. Hubungan radikal bebas dan antioksidan dengan kerusakan ginjal pada obstruksi akut. [Online]. [cited 2016 Sept 18]. Available from: http://www.urologi.or.id.

7. Rao AV, Agarwal S. Role of lycopene as antioxidant carotenoid in the prevention of chronic diseases. Nutrition. 1999;19:305-23.

8. Kanti EAA, Susianti. Pengaruh pemberian vitamin $\mathrm{C}$ terhadap gambaran histologik hepar mencit jantan dewasa (Mus musculus L) yang diinduksi monosodium glutamat. Jurnal Fakultas Kedokteran Universitas Lampung. 2012;1(1):81-90.

9. Hidayah RR, Amarwati S, Istiadi $H$. Pengaruh madu terhadap gambaran mikroskopis hepar pada tikus Wistar jantan yang diinduksi monosodium glutamat. MMM. 2015;4(4):1433-44.

10. Andreas $H$, Trianto $H$, Ilmiawan $M$. Gambaran histologi regenerasi hati pasca penghentian pajanan monosodium glutamat pada tikus Wistar. eJKI. 2015;3(1):29-36.

11. Tappi E, Lintong $P$, Loho L. Gambaran histopatologi hati tikus Wistar yang diberikan jus tomat (Solanum lycopersicum) pasca kerusakan hati Wistar yang diinduksi karbon tetraklorida $\quad\left(\mathrm{CCl}_{4}\right)$. eBm. 2013;1(3) 